Introduction

\title{
G.A. COHEN'S SOCIALISM: SCIENTIFIC BUT ALSO UTOPIAN
}

\author{
CHRISTINE SYPNOWICH \\ Department of Philosophy, Queen's University. Kingston, Canada.
}

\author{
Key Words \\ analytical philosophy; G.A. Cohen; scientific socialism; utopian socialism \\ Mots-clés \\ G.A. Cohen; philosophie analytique; socialisme scientifique; socialisme utopique
}

The death of an important scholar often occasions tributes and reminiscences about the thinker's significance and impact. The death of G.A. (Jerry) Cohen, on August 5,2009 , attests to this phenomenon to a remarkable extent. No sooner was Jerry's passing made known than there was an outpouring of expressions of sadness, affection, and esteem from many people, ranging from close friends, colleagues and students, to those who had met him but once, or whose encounters were limited to hearing him speak in a crowded lecture hall, or reading his writings.

There are many reasons for this unusual response. First, of course, there is Cohen's stature as an outstanding political philosopher and exemplary teacher. A second, crucial, reason is Cohen's personality and his unique ability to connect with people. He was a warm and generous person, with an enormous and irrepressible sense of fun and mischief, humanity and kindness; his joke- telling was legendary, as was his keen sense of friendship and loyalty.

Another reason for the huge response to Cohen's passing is the kind of political philosopher he was, whose intellectual interests were bound up with his personal commitments, the source of which were his family background. These commitments are manifest in all his writings but are particularly manifest in his recent academic inquiry into the relation between principles of justice and the obligations of those who espouse them. Born of personal experience and demanding of us that we consider our own personal relation to our political creed, Cohen's political philosophy thus has a specially compelling character.

All this accounts for, along with the many personal essays, blogs and reminiscences, the appearance of some recent significant publications paying tribute to 
Cohen's contribution (see The Journal of Ethics 2010; Sypnowich 2006; Cohen 2011). This volume of Socialist Studies/Etudes Socialistes joins them, taking as its particular focus homage to Jerry Cohen as both philosopher and socialist. The sense of profound loss is evident in the depth of philosophical engagement and keen personal connection exhibited in the papers that follow, papers that are written both by scholars who knew Cohen personally and others who did not.

In this introductory essay I consider Cohen's intellectual career in light of the themes of the essays that follow, suggesting that Cohen's work might be thought of as developing a unique conception of socialism that is, to coin a phrase, both utopian and scientific. Cohen's analytical Marxism brought a salutary rigour to left wing thought, which although it sought to transcend certain limitations in Marx's methodology, was in an important sense true to Marx's aspiration to be scientific. At the same time, however, I will contend that Cohen was also a utopian socialist in the best sense. Cohen was adamant that one should not give up on an ambitious aspiration for an emancipated human society. This is manifest in his commitment to a radical approach to justice based on "principles" rather than "facts," and moreover his contention that a consistent egalitarianism involves personal contribution to the amelioration of disadvantage. That is to say, socialism, for Cohen, would involve an ambitious conception of community, where Marx's principle of "from each according to his abilities, to each according to his needs", would guide both society's institutions and individuals' behaviour.

\section{Utopian v. Scientific Socialism}

The contrast between utopian and scientific socialism first appears in the 1849 Communist Manifesto in which Marx and Engels (1978) castigate socialists such as Robert Owen and Charles Fourier for being utopian in their methods and goals. For Marx and Engels, these early socialists are utopian because, "They reject all political, and especially all revolutionary, action; they wish to attain their ends by peaceful means, and endeavour, by small experiments, necessarily doomed to failure, and by force of example, to pave the way for the new social Gospel" (Marx and Engels 1978, 498). For Marx and Engels, the limitations of utopian socialism can be attributed in part to the under-developed character of the working class and its class struggle; the "fantastic pictures of future society" were "painted" by utopian socialists "at a time" when the proletariat was "still in a very undeveloped state" (Marx and Engels 1978, 498). According to the doctrine of historical materialism, genuine social change emanates from existing historical processes and thus the working class must seize the opportunities presented by a crisis in capitalism, rather than conceiving of revolution as an act of mere will and the realisation of good ideas. Thus Marx scoffed at "recipes for the cookbooks of the future" (Marx 1978, 299). Engels amplified this argument thirty-one years later in his essay "Socialism: 
Utopian and Scientific." There he contends that, in contrast to the utopian approach, "socialism became a science" thanks to Marx, who contributed "the materialistic conception of history and the revelation of the secret of capitalistic production through surplus value" (Engels 1978, 700).

Cohen's concern to set radical thought on a new, scientific basis did not take hold at the beginning of his career as a philosopher. His intellectual trajectory is interesting (see the introduction Sypnowich 2006). Born in 1941 to Jewish Communist parents who were active in the garment industry's union movement, Cohen grew up in a milieu of radical politics. At the age of four the young Jerry was sent to a Jewish Communist school. He stayed there until the age of eleven when the school closed after raids by the "Red Squad" of the Quebec police in an era of virulent anti-communism. He grew up thoroughly imbued with radical ideas. However, as an undergraduate at McGill University, and then as a graduate student in Oxford, Jerry did not pursue philosophy in order to develop his political ideas. Rather, under the tutelage of philosophers such as Gilbert Ryle at New College in Oxford, Cohen was keen to acquire the techniques of analytical philosophy. This was unusual; left-wing students tended to reject Oxford philosophy, regarding it, Cohen recalls, as "bourgeois, or trivial, or both." However, Cohen felt no such hostility. "I came to Oxford already steeped in Marxism, and so, unlike most of my politically congenial contemporaries, I did not look to university philosophy to furnish me with ideas that mattered..." (Cohen 1988, xi).

For some time, therefore, Cohen's politics could not be discerned in his philosophy. Moreover, when he began tackling Marxist themes as a philosopher, it was at first unaffected by the analytical approach in which he had been schooled. Like many on the Left at the time, Cohen was attracted to the work of the French Marxist Louis Althusser, whose grand statements seemed "exciting and suggestive" if difficult to pin down (Cohen 2000, xxi). By the late 1960s, however, Cohen began taking an analytical approach to Marxist questions in a number of articles, culminating in the 1978 publication of Karl Marx's Theory of History: A Defence (2000) winner of the Issac Deutscher Memorial Prize. Cohen subsequently described the volume as "homage to the milieu in which I learned the plain Marxism which the book defended," reflecting "gratitude to my parents, to the school which had taught me, to the political community in which I was raised (Cohen 2000, xxi). The book also reflected a self-conscious effort at rethinking Marxist method, to avoid the tendencies of the Left to murky thinking, tendencies to which Cohen himself, as he ruefully admits, had been prey in his poststructuralist phase, even if he had ultimately "resisted its intoxication." The book on Marx was thus, not just a tribute to the politics of his family, but also how he "settled accounts" with his "Althusserian flirtation" (Cohen 2000, xxii).

Cohen's celebrated book thus inaugurated a new school of thought of "Analytical Marxism" which counted among its adherents a diversity of left-wing scholars, all intent 
on setting tough intellectual standards for the inquiry into socialist principles. They drew on the logical analysis of philosophy, the techniques of neoclassical economics and the rational choice theory of contemporary political science. Throughout the 1980s Cohen met with his analytical Marxist colleagues regularly and published a number of articles on questions of exploitation, class, historical materialism in an analytical vein (see Cohen 1988 for a collection of some of these writings)

\section{Cohen's Scientific Socialism}

Just as Marx and Engels conceived historical materialism as a new, superior methodology for the critique of capitalism, Cohen can be said to have consciously sought a new scholarly approach, only this time informed by some of the methods and standards of analytical philosophy, and moreover producing a form of analysis critically to bear on the claims of Marxism itself. Cohen himself invited the analogy with Marx and Engels on the matter of being scientific. Cohen notes Engels's tribute to Marx as the founder of "scientific socialism" which, like Cohen and his colleagues, used "the most advanced resources of social science... within the frame of a socialist commitment," and which "exploited... what was best in the bourgeois social science of his day" (Cohen 2000, xxiii). Indeed, Cohen laments that if analytical Marxism had been called instead "scientific socialism," then Left-wing critics of analytical Marxism would not have been disposed to ask the "unproductive question" of whether analytical Marxism is Marxist (Cohen 2000, xxvii).

What makes analytical Marxism scientific? I will identify five respects, drawing on Cohen's thoughts on the subject, as well as his philosophical writings. The first respect can be described as a broad commitment to philosophical sharpness. This, paired with an unabashed commitment to socialist ideals, meant that Cohen had an invigorating impact on Oxford political philosophy when he returned in 1985 to take up the Chichele Chair in Social and Political Theory at All Souls College. For Cohen, claims should be precise and clear; arguments should be disciplined and rigorous. These qualities are conveyed in the famous avowal that analytical Marxism was "no-bullshit" Marxism. The analytical Marxist responds to criticism by taking "precise measure of the force of the assault in order to alter his position in a controlled and scientifically indicated way." The bullshitter, in contrast, "simply shifts to another unthought-through and/or obscure position, in order to remain undefeated" (Cohen 2000, xxvi).

Thus Cohen took issue with Marxism itself and some of its substantive commitments. For example, Cohen targeted the Marxist theory of history which he contended was seriously impaired by what he dubbed the "obstetric" view of the inevitable birth of communism from capitalist preconditions (Cohen 2000a, 75-77). Marxism is almost unique in its aspiring to be, not just a normative theory about the 
injustice of capitalism and the superiority of communism, but also a predictive theory which forecasts the demise of one social order and its replacement by a superior alternative. For Cohen, the predictive aspect is "patently false," and moreover exemplifies the tendencies of Marxism to resist real standards of confirmation since the Marxist can keep altering the temporal measure in order to salvage its predictive claims.

Connected to this is a second way in which Marxism is infected with wooly thinking: that is, its lack of specification of the nature of communism itself, particularly its relations of justice. For Cohen, attending to this gap in the Marxist tradition certainly did not imply soft-pedalling the radicalism of Marxian ideals. This lacuna prompted Cohen to look outside of the Marxist tradition and consider liberal debates for more precise rendering of the principle of mitigating disadvantage.

Cohen began by analysing the work of the libertarian Robert Nozick and his conception of self-ownership. Nozick's ideas had many affinities with Marx's idea of proletarian exploitation and the claim that the individual is sovereign over his or her person and powers. However, for Cohen, in the libertarian case, the commitment to private property takes precedence over the ideal of the person as free, self-determining being; in Cohen's compelling argument, Marxism emerges as the philosophy with the more principled stance on liberty. Marxism recognises how property relations can constrain a person's opportunities and powers, so that, in order to defend freedom, one must attack private property.

One of Cohen's papers in this period had the subtitle "Why Nozick Exercises some Marxists more than he does any Egalitarian Liberals," (Cohen 1990) to communicate the irony that thinkers at some distance from libertarians on the political spectrum have more in common with libertarians than do their politically more proximate liberal bedfellows. But the allusion to egalitarian liberals also presaged another focus in contemporary political philosophy that was to emerge in Cohen's writings. By the 1980s, the era of glasnost and Thatcher, Cohen was investigating the principles and arguments of contemporary liberal egalitarianism.

For Cohen, the most important arguments for redistributing wealth were coming from liberals such as Rawls. However, Rawls's argument for redressing the position of the worst off had several problems. Rawlsian justice was premised on the arbitrariness and injustice of inequality, and yet it conceded that the productivity necessary to attend to the have-nots might require incentives that permit the wealthy to retain much of their economic advantage. This raised a larger question about the extent to which theories of justice should be construed as regulative policies tailored to non-ideal circumstances, or principles that transcended matters of fact.

Third, Cohen took the view that a defining feature of rigorous thought was that it eschew the kind of holism antithetical to the detailed analysis of particulars in their own right; "micro-analysis is always desirable and always in principle possible" (Cohen 2000, 
xxiii). Indeed, Cohen unabashedly deployed scientific vocabulary on this point, urging "resolution to a more atomic level." Pre-analytical Marxism was "scientifically undeveloped," according to Cohen:

... rather in the way that thermodynamics was before it was supplemented by statistical mechanics, and, in each case, because of failure to represent molar level entities (such as quantities of gas, or economic structures) as arrangements of their more fundamental constituents. It is one thing to know, as phenomenological thermodynamics did, that the gas laws hold true. It is another to know how and why they do, and that further knowledge requires analysis, in the narrow sense, which statistical mechanics provided by applying Newton's laws to the molecular constituents of gases. Partly similarly, to claim that capitalism must break down and give way to socialism is not yet to show how behaviours of individuals lead to that result. And nothing else leads to that result, since behaviours of individuals are always where the action is, in the final analysis (Cohen 2000, xxiii-xxiv).

This focus on the particular, the idea of isolating a particular question from more general themes or ideas, made for a tough-minded approach whereby socialist commitments had to be parsed into distinct premises and conclusions and tested for their validity.

A fourth respect in which Cohen's method is self-consciously scientific is that he considers philosophical inquiry to involve intellectual progress, building on previous rudimentary understandings to come closer to the truth, just as scientists build on past discoveries in their investigations to find the explanatory structures that disclose the character of observed events. Thus Cohen criticises Jon Elster for being "too insistently analytical" in his rejection of functional explanation, noting that "analytical Marxists can disagree about what stage a particular discipline or sub-discipline had reached or should be expected to have reached, on pain of condemnation as unscientific..." (Cohen 2000, xxiii). This "progressivist" view is apparent also in Cohen's analogy with science referred to above: Pre-analytical Marxism was "scientifically undeveloped," according to Cohen, "... rather in the way that thermodynamics was before it was supplemented by statistical mechanics."

Related to this is a fifth sense in which analytical Marxism purports to be scientific. This is its anti-pluralism. Analytical Marxists have no truck with other approaches. This might seem at odds with the openness of Cohen to non-Marxist political philosophies; after all, he was certainly prepared to find merit in liberal, even libertarian argument. However, this openness was of course in part born of his 
frustration with what he saw as the paucity of traditional Marxism. It was the analytical nature, in large part, of liberal views which made their influence salutary.

According to Cohen, before analytical Marxism, there may have been nonanalytical Marxist theories which were intellectually respectable. However, once these theories encounter analytical Marxism, then they "must either become analytical or bullshit." The analytical Marxist, it would appear, considers his Marxism as "uniquely legitimate." Here we see an affinity with a feature of the thought of Marx and Engels that is not wholly attractive. Consider the Communist Manifesto's scathing dismissal of other socialist views:

In proportion as the modern class struggle develops and takes definite shape, this fantastic standing apart from the contest, these fantastic attacks on it, lose all practical value and all theoretical justification. Therefore, although the originators of these systems were, in many respects, revolutionary, their disciples have, in every case, formed mere reactionary sects (Marx and Engels 1978, 498-499).

Of course, the issue of pluralism is tricky. Different approaches may shed light on different aspects of the socialist ideal. More discursive analyses might be illuminating of some questions not considered by analytical Marxists. Rejecting outright all other approaches other than one's own, however much one's approach seems superior to others, can thus seem dogmatic.

It might appear Cohen himself had something like this thought in mind when he advised his students to entertain seemingly foggy notions as they philosophise: "One should aspire to clarity, but one should not avoid possible insight for the sake of avoiding unclarity." However, I think this tip was intended not to confirm the value of alternative ways of doing philosophy but rather as an acknowledgement of the halting steps one must take in the uniquely valuable analytical project of aspiring to clarity (Cohen 2011, 224225). Thus for Cohen if one eschews relativism and seeks truth, a diversity of intellectual positions indicates confusion, not greater insight. Moreover, Cohen would say analytical Marxists are prepared to have their arguments corrected; indeed, that is, among other things, what distinguishes them from "bullshit Marxists".

Thus the analytical Marxists did not agree on a number of questions; take for example Cohen and Elster's dispute on the question of functional explanation. It is just that analytical Marxists are unmoveable on the question of what method is best placed to reveal the defects of an argument. Nonetheless, there is something somewhat disquieting about this insistence on one path to philosophical enlightenment. Moreover, in a postSoviet era, one cannot help but wonder if this severity about doctrine seems a holdover of 
old-style orthodox Marxism which had illiberal political consequences so abhorred by Cohen.

Some academics keen on rigorous analysis can be callous or dismissive. Cohen, in contrast, was always humane in his dealings with those less analytically minded. It might be said that Cohen's students would often find in his manner a kind of intimidating fierceness about philosophical rigour, even if he was at the same time encouraging, affectionate and kind. It was often difficult to follow the wise counsel he gave his diffident followers: "a bad way to never make a mistake is to shut up and say nothing" (Cohen 2011, 225) if one feared that what one would say would not meet his high standards. However, the significant philosophical contributions of a number of Cohen's students suggest his tutelage - both tough and kind - worked. His "take no-prisoners" approach to Marxist theory set a standard that inspired students even if it also may have scared some of them a little. Certainly Cohen's uncompromising commitment to analytical rigour made for a scientific approach to Marxism which had a profound impact on the development of contemporary political philosophy.

\section{Cohen's Utopian Socialism}

Cohen was in a significant sense a utopian socialist, not in Marx's sense of offering 'fantastic' predictions about an ideal future, but insofar as he was prepared to endorse a radical alternative to existing society. Moreover, for all his fierce denunciation of sloppy philosophising, the harsh critic also possessed a fundamental sympathy for his fellows, whose needs and interests are crucially, he contended, the responsibility of us all. If we profess to be egalitarians we should not just look to the state to execute the principles of justice; but rather ourselves endeavour, in our everyday activity, to realise our political commitments.

If this sounds a little moralistic, it ought to be stressed that Cohen was not preachy or sanctimonious. Indeed, he bristled a little at the title for the collection of essays in his honour, noting with his usual wit that the "egalitarian conscience" might suggest that he is "holier than I am. I am certainly not holier than I am; indeed, it's a good bet that I am not even holier than thou." The idea of an egalitarian conscience, he feared, made him seem "so grim, so inspecting, so admonishing, so unremittingly judging" (Cohen 2006, 249). Cohen judged bad philosophy strictly, but he was not a strict person; he was certainly not a puritan about his socialism. In conversation he expressed impatience with puritanical figures such as Orwell or Wittgenstein who lived, at times, as though to be an egalitarian involved a kind of purity, a foreswearing of earthly pleasures.

The idea of conscience remains illuminating. Generosity, a constitutive feature of Cohen's character is exemplified by his conception of socialism itself, where people live in fellowship, sharing resources in a commitment to egalitarian principles of distribution 
regardless of talent or ability. In Cohen's last publication, Why Not Socialism? (2009) he elaborates this idea with the example of a camping trip where resources are shared on the basis of need, and all contribute what they can. In such a context, inequalities that are permissible according to the bar of justice - e.g. those that result from individuals' decisions to work less hard or take risks with their share of resources - might be problematic by what might be called the criterion of community. Inequality undermines reciprocity; if you are poor, however much the result of your own choices, you are cut off "from our common life" (Cohen 2009, 36-39). Cohen endorsed "luck egalitarian" theories which held the mitigation of disadvantage applied only in cases of bad brute luck, rather than "option luck" where deliberate gambles or foolish decisions left one badly off. But he recognised that such arrangements, though just, would adversely affect community, an important egalitarian value.

This little book, which has come to prominence since Cohen's death, has prompted some controversy about Cohen's relationship to liberal egalitarian justice. I noted that when Cohen began looking at political philosophy outside the Marxist tradition, he turned first to the work of the libertarian Robert Nozick; however, his main focus came to be the work John Rawls, and his liberal egalitarianism, since individualism about labour and resources had to give way, he thought, to the principle of redistribution. Cohen deployed the same analytical method as Rawls, but he took issue with Rawls's position, arguing for what might be thought of as a truer Marxian approach to capitalist inequality, which calls for a transformation in consciousness and a more thorough-going egalitarianism. Rawls was thus, it may be said, insufficiently utopian by Cohen's lights. (Of course, for libertarians such as Jan Narveson in this volume, Rawls himself is problematically redistributive. ${ }^{1}$ ) Readers of the interesting paper by Duan Zhongqiao and Yi Lang on Cohen's influence on Chinese philosophy might conclude that in light of the example of a society with both a precarious commitment to socialist equality and a persisting attachment to murky dialectical thinking, Cohen's combination of scientific method and utopian ideals is salutary indeed.

The question of how much equality might demand of us became the centrepiece of Cohen's later work. 'If You're an Egalitarian, How Come You're So Rich?' (see Cohen 2000 (a) and Cohen 2001) was the humorous title that Cohen formulated to pinpoint his misgivings about how little Rawlsian justice can demand of people's personal commitments. The title is, of course, irresistible, prompting wry grins among students at

\footnotetext{
1 'There is not, it seems to me, a genuine case for the egalitarian principle, and thus for regarding a justification along the lines of "incentives" as prerequisites for legitimizing our perfectly normal behaviour in markets and other contexts of social life - much less for regarding these as injustices that we perforce had probably best put up with under the circumstances.'
} 
its very mention, and some imitations. ${ }^{2}$ Libertarians such as Narveson get a rejoinder in Colin Macleod's paper where he takes up the question of the rich egalitarian to suggest it is the libertarian who is particularly vulnerable to this challenge. After all, if the libertarian argues that charity, not state redistribution, is the just way of remedying disadvantage, the personal burden would seem particularly acute for the rightwing critic of social justice. David Rondel, in contrast, suggests that the demand that principles of distributive justice bear on people's personal choices lacks an important premise about whether any inequality not remedied by social institutions is sufficiently "morally serious" so as to warrant an extension of duty to individual citizens. Pablo Gilabert has a similar point in mind when he commends sufficientarianism, wherein the distributive principle seeks to ensure all members of the community have sufficient resources, which he argues is the most congenial to Cohen's embracing of community.

Some commentators wonder whether any theories of liberal justice can survive Cohen's criterion of community. Jeffrey Noonan also focuses on the sufficiency criterion, contending that Cohen's socialism is "not essentially an egalitarian doctrine" since the Marxist ideal of communist society is better understood as founded on the principle of life sufficiency rather than a "bourgeois perspective of invidious interpersonal comparisons that any abstract metric of equality presupposes." For Nicholas Vrousalis, the ideal of community is not a supplement to justice, it contradicts it, and thus Cohen's more radical Marxist ideal of decommodification casts considerable doubt as to whether even a revisionist liberal egalitarianism is compatible with socialist community.

It can be argued that the ideal of community which seeks flourishing lives for all members, rather than the acquisition of goods, is not in fact founded on the principle of equality. Recall Marx and Engels's own disdain for the bourgeois criterion of "equal right" and their contention that whilst it may be useful as a transitional principle in the fledgling socialist society, the ideal communist society would transcend such parsimonious measuring of one's due with the communist ideal of the satisfaction of need. In light of this, it is a suggestive claim that the Marxist Cohen was in some sense at odds with himself in looking to liberal egalitarianism to correct the vagaries of the socialist tradition.

However, to separate the two parts of Cohen is to diminish what is among his most compelling contributions: the marriage of justice and community. Justice involves community insofar as remedying inequality involves, in its most ambitious form,

\footnotetext{
2 I've encountered in paper titles, blogs, reviews, the following: 'If you're an egalitarian how come you're trying to sell an undergraduate arts degree that costs more than an MBA?' '...how come you're a philosopher?' '...how come you claimed so much in expenses?' '...how come you wanna be so poor?' '...how come you don't believe in genetic enhancement?' '...how come you read bedtime stories to your children?' '...how come you're so inegalitarian about your body?' '... how come you send your children to private school?'
} 
foregoing the idea that distribution must be based on market success. Community, according to Cohen, is expressed in the "antimarket principle according to which I serve you not because of what I can get in return by doing so but because you need or want my service" (Cohen 2009, 39). Thus, for Cohen, Rawls's difference principle fails the test of community, but it also fails by Rawls's own lights, that of justice, which depends on the ideal of community in order to override the logic of the market. Theories of justice which permit constraining egalitarian distribution for reasons of incentives betray their own principles. If all members of the community are committed to the principle of equality, the talented among them cannot turn around and demand higher pay. To do so is to put them, as Cohen says, "outside the community" (Cohen 2009 (a), 32).

This critique of incentives is part of the view that, contra Rawls, a theory of justice should require that individuals devote themselves to the remedy of inequality in their personal choices more generally, rather than conceiving of the pursuit of egalitarian distributive principles as the prerogative of state institutions. There may be pragmatic grounds for falling short of these demanding egalitarian principles, given facts about human behaviour, but Cohen insists these facts should have no part in a theory of justice. Rawls, he contends, misidentifies the question of justice with the question of what principles we should adopt to regulate our affairs. And while "facts may constrain possibilities of implementation and determine defensible trade-offs (at the level of implementation) among competing principles", the principles themselves are unaffected by such considerations. "Failure to distinguish between rules of regulation and the principles that justify them leads to confusion of different questions" in particular, questions about decisions and action as opposed to norms and ideals (Cohen 2009 (a), 269).

Whether Cohen was fair to Rawls is a matter of considerable debate. Loren King in this volume suggests that Cohen misconstrues Rawls's purpose, since justice as fairness refers not just to matters of regulation but also the way in which we should arrive at mutually acceptable regulative principles consistent with our conceptions of justice. It is for this reason that King suggests that although Rawls and Cohen are at odds over the concept and conception of justice, they might in fact converge over the more practical matter of regulative principles. For his part, Alistair Macleod avows that strands in Rawls's writings commit him to positions at no great distance from those Cohen favours despite the fact that these positions are at variance with some of Rawls's most familiar expressed views. For King, Rawls in fact sought optimal principles of regulation that might be consistent with a variety of conceptions of justice. I am not sure that Cohen would have agreed; after all, he concedes that we may need to settle for Rawlsian regulation in the imperfect institutions of justice within which we find ourselves. But that is a long way from the ideal of justice itself. And this ideal is central for Cohen. 
Interestingly, whilst some commentators find the influence of Rawls at odds with Cohen's Marxism, rendering it too moderate, others contend that Cohen's critique of Rawls makes him insufficiently Marxist. The latter objection centres on the compatibility of utopianism and realism in egalitarian theory. For the charge is, in essence, that the utopianism of Cohen is at odds with his claims to being scientific.

The target here is Cohen's argument for a theory of justice that eschews the domain of facts, which it is argued, undermines the claims of Cohen to providing, like Marx, a scientific approach to radical politics. Lea Ypi's essay draws on Plato's dialogue Parmenides to suggest infinite regress threatens Cohen's search for ultimate factindependent principles. Particularly interesting is her suggestion early in the paper that the eschewal of facts is profoundly un-Marxist. Cohen's preoccupation with high theory divorced from political action is in tension with his Marxist position since "in the case of Marx, any attempt to isolate principles from the world of facts, any theoretical stance which is also not a political one cultivates a doctrinaire spirit." Likewise Kai Nielsen takes issue with Cohen's more recent work, finding it at odds with his "masterful" work on historical materialism; moreover, he contends, such metaethical accounts, even if they are right, have little to do with the project of socialism. The worry about the utility of political philosophy also prompts Kofman to complain that "some consideration" of how theories "bear on the facts of the human condition" is essential for their justification.

It is worth pondering the role of utopianism in political thought. Political philosophy is distinctive in that in its very effort to address the normative question of how we are to live in common, it must take account of an empirical reality which throws up, for example, the problem of scarcity, the constraints of human nature, the dynamics of social change. The more radical our political philosophies, the more they seek to transcend this empirical reality. To that extent they inevitably risk looking utopian, being unrealistic or ungrounded in the facts of politics and power. Yet of course political philosophy cannot be reduced to a mere assent to the world as we find it; it must be a normative enterprise, concerned with human progress and social improvement. So it is related to the utopian, in some sense, at least in its aspiration. Thus Cohen feared that if justice and equality were not "rescued" from "facts," the result would be a diminished ambition for normative political theory. Here "utopian" means articulating principles, established independent of factual considerations, and arguing that political reality should be made to conform to them. Of course, the principles established by such a method may be very minimal in their aspirations and thus the society that conformed to them would not have the characteristics normally associated with a utopia. However, in Cohen's case, the principles constitute a vision of society that is thoroughly egalitarian, and to that extent it might be dubbed utopia.

\section{Conclusion}


Jerry Cohen's final contributions affirm his commitment to an ambitious ideal of socialism, derived from Marx's idea of "communist man" who transcends narrow bourgeois egoism. In essence, Cohen is a utopian socialist - not in the sense attacked by Marx, where one simply posits a better society without thinking about the historical circumstances that might get us there - but in the best sense of proposing a robust set of egalitarian ideals. This is evidenced in his insistence on a radical approach to justice based on "principles" rather than "facts," and moreover his contention that a consistent egalitarianism involves personal contributions to the pursuit of equality. In Cohen's insistence that the ambitions of political theory should transcend the world of facts, many thought he had parted company with the scientific basis of the Marxist tradition, suggesting that Marx's critique of utopian socialism would ironically apply to Cohen himself, the political philosopher who counted his most important achievement to be the revival of a scientific approach to socialist ideals. However, for Cohen, what makes Marxist political philosophy scientific is not the data of science, but an approach characterised by rigour and discipline. Indeed, for Cohen, the project of distinguishing facts from principles was itself illuminated by the application of such a scientific approach.

Cohen was right to demand that political philosophy be understood within the domain of ideals. A political theory that seeks to dispense with utopian objectives, the aspiration to an ideal, is paradoxically, utopian itself. Utopia per se is of course not a live option; the ideal society will always be beyond the grasp of flawed mortals. But some kind of utopian imperative, such as that of equal human flourishing, community, the equal realisation of human needs, which seeks to go beyond the given, is essential to the very task of political philosophy, and certainly the political philosophy of G.A. Cohen. We should, like Cohen, affirm the utopian aspiration in political philosophy without falling prey to a utopianism about how to achieve that aspiration.

To the surprise of many of his friends and admirers, towards the end of his life Cohen defended the conservative idea of "conserving intrinsic value." Cohen insisted this "conservative attitude" involved an appreciation for the fleeting things of value that are vulnerable to change and destruction. Cohen's conservatism, he underscored, did not entail a conservative view on matters of justice; indeed, he noted that sometimes social change is required to protect those things of value, "to revolutionize our situation." $\mathrm{He}$ noted that "one thing Karl Marx said about the socialist revolution was that that revolution was necessary to preserve the fruits of civilization against the ravages of capitalism" (Cohen 2011 (a)). The idea of preserving value is perhaps what animates this volume itself - to hold on to the ideas and the example of a unique philosopher and socialist. Essential to Cohen's uniqueness is that he was both scientific and utopian, and that marriage made for a particularly stimulating and rigorous intellectual contribution 
that we should cherish and nurture. As Jerry said to me once, quoting Ezra Pound: "what thou lovest well remains, the rest is dross."

\section{References}

Cohen, G.A. 1988. History, Labour and Freedom: Themes from Marx. Oxford: Oxford University Press.

Cohen, G.A. 1990. "Marxism and Contemporary Political Philosophy, or: Why Nozick Exercises Some Marxists more than he does any Egalitarian Liberals". Canadian Journal of Philosophy. Supplement 16: 363-387.

Cohen, G.A. 2000. Karl Marx's Theory of History: A Defence. Expanded edition. Princeton: Princeton University Press.

Cohen, G.A. 2000 (a). “If You're an Egalitarian, How Come You're So Rich?”. Ethics. 4:126.

Cohen, G.A. 2001. If You're An Egalitarian, How Come You're So Rich? Cambridge: Harvard University Press.

Cohen, 2006. “Thanks.” In The Egalitarian Conscience: Essays in Honour of G.A. Cohen. Edited by Christine Sypnowich. Oxford: Oxford University Press: 249-50.

Cohen, G.A. 2009. Why Not Socialism? Princeton: Princeton University Press.

Cohen, G.A. 2009 (a). Rescuing Justice and Equality. Cambridge: Harvard University Press.

Cohen, G.A. 2011. On the Currency of Egalitarian Justice and Other Essays in Political Philosophy. Edited by Michael Otsuka. Princeton: Princeton Unviersity Press.

Cohen, G.A. 2011 (a). "Rescuing Conservatism: A Defence of Existing Value." In Reasons and Recognition: Essays on the Philosophy of T.M. Scanlon. Edited by R. Jay. Wallace, Rahul Kumar and Samuel Freeman. Oxford: Oxford University Press: 203-230. 
Corlett, J. Angelo, editor. 2010. "Special Double Issue: The Person and Work of Gerald Allan Cohen". The Journal of Ethics. 14:3-4.

Engels, Fredrich. 1978. "Socialism: Utopian and Scientific". In The Marx-Engels Reader. Edited by Robert C. Tucker. New York: W.W. Norton.

Marx, Karl. 1978. “Afterword: Capital, Volume 1". In The Marx-Engels Reader. Edited by Robert C. Tucker. New York: W.W. Norton.

Marx, Karl and Fredrich Engels. 1978. “The Communist Manifesto”. In The Marx-Engels Reader. Edited by Robert C. Tucker. New York: W.W. Norton.

Sypnowich, Christine, editor. 2006. The Egalitarian Conscience: Essays in Honour of G.A. Cohen. Oxford: Oxford University Press. 